\title{
Negative Integer
}

National Cancer Institute

\section{Source}

National Cancer Institute. Negative Integer. NCI Thesaurus. Code C75942.

An integer with a value less than zero. 